\section{OPEN ACCESS}

Edited by:

Ariane Berdal,

INSERM U1138, Centre

de Recherche des Cordeliers, France

Reviewed by:

Michel Goldberg,

Institut National de la Santé et de la

Recherche Médicale (INSERM),

France

Eric Everett,

University of North Carolina at

Chapel Hill, United States

*Correspondence:

Rozita Jalall

Rozita.jalali@UCSF.edu;

r.jalali@acta.nl

Specialty section:

This article was submitted to

Craniofacial Biology and Dental

Research,

a section of the journal

Frontiers in Physiology

Received: 19 March 2018

Accepted: 28 May 2018

Published: 26 June 2018

Citation:

Al-Ansari S, Jalali R, Plotkin LI, Bronckers ALJJ, DenBesten P,

Zhang Y, Raber-Durlacher JE, de Lange J and Rozema FR (2018)

The Importance of Connexin 43

in Enamel Development and Mineralization.

Front. Physiol. 9:750.

doi: 10.3389/fphys.2018.00750

\title{
The Importance of Connexin 43 in Enamel Development and Mineralization
}

\author{
Sali Al-Ansari', Rozita Jalali2*, Lilian I. Plotkin'3,4,5, Antonius L. J. J. Bronckers ${ }^{6}$, \\ Pamela DenBesten ${ }^{2}$, Yan Zhang ${ }^{2}$, Judith E. Raber-Durlacher ${ }^{1,7}$, Jan de Lange $^{7}$ and \\ Frederik R. Rozema ${ }^{1,7}$
}

'Department of Oral Medicine, Academic Center for Dentistry, Amsterdam, Netherlands, ${ }^{2}$ Department of Orofacial Sciences, School of Dentistry, University of California, San Francisco, San Francisco, CA, United States, ${ }^{3}$ Department of Anatomy and Cell Biology, Indiana University School of Medicine, Indianapolis, IN, United States, ${ }^{4}$ Roudebush Veterans Administration Medical Center, Indianapolis, IN, United States, ${ }^{5}$ Indiana Center for Musculoskeletal Health, Indianapolis, IN, United States, ${ }^{6}$ Department of Oral Cell Biology, Academic Center for Dentistry, Amsterdam, Netherlands, ${ }^{7}$ Department of Oral and Maxillofacial Surgery, Amsterdam Medical Centre, University of Amsterdam, Amsterdam, Netherlands

During enamel development, formation of hydroxyapatite crystals and regulation of $\mathrm{pH}$ in the enamel matrix require massive transport of ions. Both ameloblasts and adjacent dental epithelial cells in the stellate reticulum co-express several transmembrane cotransporters/ion-exchangers for transport of ions across plasma membranes. Gap junctions (GJs) enable intercellular exchanges of ions between neighboring cells. This suggests that the ameloblasts and other cell layers of the enamel organ, form a functional unit. During the bell stage of tooth formation, the non-ameloblast dental epithelium highly expresses the $\mathrm{Na}-\mathrm{K}-\mathrm{Cl}$ cotransporter (Nkcc1). Nkcc1-null mice are associated with enamel hypomineralization and increased expression of GJ protein connexin 43 (Cx43), suggesting that reduced ion transport in the Nkcc1-null mouse is in part compensated by increased intercellular ion transport through GJs. To understand the role of GJs in ion transport and its effect on $\mathrm{pH}$ regulation, we examined in a mouse strain in which $\mathrm{C} \times 43$ was ablated selectively in DMP1 expressing cells ( $\mathrm{C} \times 43^{\text {flox }}$ /flox mice crossed with DMP1-8kb-Cre mice), including ameloblasts. Micro-CT analysis showed that the mineral density at late maturation stage incisal enamel of the Cx43-null mice was $10 \%$ less than in controls, whereas that in dentin was unchanged. Maturation stage ameloblasts of mice lacking the $\mathrm{pH}$ regulating sodium/bicarbonate transporter NBCe1 (Nbce1-null), or chloride channel Cftr (Cftr-null) were found to have increased Cx43-immunostaining. These results support the possibility that GJs in the ameloblastpapillary complex at the maturation stage contribute to ion transport by enabling passage of ions directly from cells of the papillary layer into ameloblast layer. Increasing the number of GJs may partly compensate the reduction of ion-cotransporters and ion exchangers in dental epithelium.

Keywords: enamel, hypomineralization, microCT, mineralized tissue development, ameloblast, connexin 43 


\section{INTRODUCTION}

Dental enamel is the hardest substance in the human body. Enamel mineralization is an active process, regulated by enamel organ cells, including ameloblasts, stratum intermedium cells, stellate reticulum, and the papillary layer. Secretory stage ameloblasts differentiate from pre-ameloblasts to synthesize and secrete proteins into the matrix space to form the full thickness of matrix, into which long thin hydroxyapatite crystals grow. At the end of the secretion stage, capillaries invaginate the stellate reticulum layer, which overlies ameloblasts, to form the papillary layer, which is rich in capillaries. After a short transition stage there is a rapid increase in mineral deposition into the matrix, which is the start of the maturation stage (Nanci, 2012). During the maturation stage enamel proteins are removed from the enamel space and calcium and other ions necessary for enamel formation are deposited (Smith, 1998). The differentiating enamel organ is thought to be solely responsible for all these activities (Elwood and Bernstein, 1968). At the maturation stage, expression patterns of the ion exchangers of SLC4A4 (NBCe1) and $\mathrm{Na}^{+}-\mathrm{K}^{+}$-ATPase (Lacruz et al., 2010b; Jalali et al., 2014; Wen et al., 2014), in both ameloblasts and papillary cells, suggest that both layers form a functional unit to regulate the hemostasis of ion sodium and potassium exchange to direct matrix mineralization. Changes in the structure of the papillary layer between early and late maturation stages may reflect changing rates of calcification or of resorption of enamel proteins.

Ameloblasts and papillary cells are likely to communicate with each other through cell-cell junctions. In general, cell-cell junctions, including adherents junctions, tight junctions, and gap junctions (GJs) participate in cell-cell communication. Among those cell-cell junctions, GJs are the only junction type that allows direct intercellular ion exchange. Connexins are trans-membrane Connexins (Cxs) proteins that can form intercellular channels to allow ion and small molecule $(<1.5 \mathrm{kDa})$ exchange between cells (Evans and Martin, 2002). Twenty-one different Cx isoforms have been identified in humans and twenty $\mathrm{Cx}$ isoforms in mice (Söhl and Willecke, 2004). Cx43 is highly expressed in rodent incisors, molars and the cells forming the human tooth during development, including the ameloblasts, stratum intermedium, stellate reticulum, papillary layer, and odontoblasts (João and Arana-Chavez, 2003, 2004; Toth et al., 2010).

Mutations in connexin genes lead to alterations in important biological functions of GJ channels and hemi channels, disturbing intercellular communication (Laird, 2006). Mutations in human $\mathrm{Cx} 43$ results in oculodentodigital dysplasia (ODDD), an autosomal-dominant disorder characterized by anomalies of face, eyes, limbs, and teeth (Paznekas et al., 2003). The most common symptoms are enamel hypoplasia, microdontia, microcornea and craniofacial, skeletal and skin alterations (Weintraub et al., 1975; Gladwin et al., 1997; Paznekas et al., 2003, 2009). Mice lacking $\mathrm{Cx} 43$ die within hours after birth because of cardiac malformations precluding the study of the adult skeleton (Langille et al., 1995). Dominant negative G60S mutants of Cx43 (Flenniken et al., 2005) mice have an altered enamel organ morphology and enamel hypoplasia (Toth et al., 2010). Recently, we found that expression of $\mathrm{Cx} 43$ was enhanced in enamel organ of mice lacking $\mathrm{Nkccl}$ suggesting that increased numbers of GJs may compensate for deficient ion transport by transmembrane cotransporters, including downregulation of Nkccl (Jalali et al., 2017).

In this study we tested the hypothesis that GJs contribute to enamel formation by enabling passage of ions from papillary layer into ameloblasts. We examined this by comparing the expression of $C X 43$ protein in the enamel organs of $\mathrm{Cx} 43$ deficient in ameloblasts $\left(C x 43^{\text {flox/flox;DMP1-Cre }}\right)$. Our further characterization of Cx43 in enamel organs of $\mathrm{Cftr}$ and $\mathrm{Nbce1}$ null mice, both of which transport ions involved in ameloblast regulation of $\mathrm{pH}$ on the forming extracellular enamel matrix (Bronckers et al., 2010; Jalali et al., 2014) supported our hypothesis by showing a compensatory upregulation of $\mathrm{Cx} 43$ in these mouse models.

\section{MATERIALS AND METHODS}

\section{Tissues}

One-month-old male mice lacking $\mathrm{Cx} 43$ cells expressing DPM1 (Cx $\left.43^{\text {flox/flox; DMP1-8kb-Cre }}, N=4\right)$ and control littermates $\left(\mathrm{Cx} 43^{\text {flox/flox }}, N=5\right)$ were generated and genotyped as previously described (Bivi et al., 2012). Other mouse strains and procedures for this study have been described before (Bronckers et al., 2010; Jalali et al., 2014). For each genotypic mouse strain, teeth, and enamel organs from three wild type mice and three null mutant mice were analyzed and compared. All animal procedures were approved by the Committee for Animal Care using standards for treatment of animals (University of Amsterdam), the Animal Care and Use Committee of the National Institute of Dental and Craniofacial Research, National Institutes of Health (ASP 13686), and the Institutional Animal Care and Use Committee of Indiana University School of Medicine.

\section{Histological Procedures}

Upper and lower jaws of wild type, Cx43 $3^{\text {flox/flox; DMP1-8kb-Cre, }}$ $\mathrm{Cx} 43^{\text {flox/flox }}, \mathrm{Nbce1}$ null, and Cftr- null mice were fixed by immersion in 5\% paraformaldehyde in $0.1 \mathrm{M}$ phosphate buffer $\mathrm{pH}$ 7.3. Hemimandibles were then decalcified in 4\% EDTA, $\mathrm{pH}$ 7.3 for 2 weeks at $4^{\circ} \mathrm{C}$ and processed into paraffin. Sagittal serial sections in thickness of 5-7 $\mu \mathrm{m}$ were prepared and mounted on polylysine coated glass slides.

\section{Immunohistochemistry}

Dewaxed sections were rinsed in phosphate buffered saline (PBS) and subjected to antigen retrieval in $10 \mathrm{mM}$ citrate buffer $\left(\mathrm{pH} 6.0\right.$ ) either at $60^{\circ} \mathrm{C}$ overnight, or for $20 \mathrm{~min}$ at $95^{\circ} \mathrm{C}$ in a microwave oven. After antigen retrieval, endogenous peroxidase was blocked with a peroxidase block solution (Envision kit, Dakocytomation) for $5 \mathrm{~min}$. Sections were washed in TBST (3x). Non-specific staining was blocked for $30 \mathrm{~min}$ with $2 \%$ BSA. Sections were then incubated overnight at $4^{\circ} \mathrm{C}$ with rabbit anti-Connexin-43 (Cx43) (Abcam, Catalog No. Ab11370). Matched non-immune IgG (1:200 to 1:300) or normal serum (same concentration as primary antibodies) served as controls. After overnight incubation at 
$4^{\circ} \mathrm{C}$ with primary antibodies, sections were washed three times in TBS and incubated with goat anti-rabbit IgG antibodies conjugated with peroxidase (EnVision Kits) for $1 \mathrm{~h}$ at room temperature and counterstained with hematoxylin. Otherwise, rabbit anti-Cx43 was visualized by goat antirabbit Alexa Fluor 488 (5 $\mu \mathrm{g} / \mathrm{mL}$; Invitrogen) after $1 \mathrm{~h}$ incubation at room temperature and counterstained with DAPI (Vector Laboratories, Burlingame, CA, United States). Immunohistochemistry images were acquired with Leica EL6000 or Axio Zoom V16 microscope.

\section{Microcomputed Tomography (microCT)}

To determine the degree of mineral content, hemi-mandibles from $\mathrm{Cx} 43^{\text {flox/flox; DMP1-8kb-Cre }}, \mathrm{Cx} 43^{\text {flox/flox }}$ mice were scanned at a resolution of $8 \mu \mathrm{m}$ voxel using a $\mu \mathrm{CT}-40$ high resolution scanner (Scanco Medical, AG, Bassersdorf, Switzerland). Mineral density was determined at sequential stages of development. Cross-sectional virtual images were collected from the most developed (incisor tip) to the least developed (cervical) area. The most incisal slice containing the most mineralized enamel was identified visually. Measurements were made at $500 \mu \mathrm{m}$ intervals (50 slices at $10 \mu \mathrm{m}$ interval) and slices at the same developmental stage from three mice per group were averaged and plotted as function of stage (slice number). Independent $t$-test was used to compare the groups. Statistical significance was set at $p<0.05$ level.

\section{Western Blotting}

From freeze-dried wild type and Cftr null mutant mandibular incisors early maturation stage enamel organs were micro dissected incisally based on a reference line projected between the first and second molars (M1 and M2), to separately dissect secretory and maturation stage ameloblasts, as described before (Schmitz et al., 2014). The apical, secretory, half of the enamel organ was placed in SDS loading buffer (from Nucleospin Triprep kit, Macherey-Nagel, supplied by Bioke, Leiden, Netherlands) and protein was measured using the BCA protein assay (Bio-Rad, Hercules, CA, United States). Twenty $20 \mu \mathrm{g}$ of enamel organ denatured protein and $10 \mu \mathrm{g}$ of molecular weight markers $\left(\right.$ Novex $^{\circledR}$ Sharp Pre-stained Protein Standard (\# LC5800) or SeeBlue ${ }^{\circledR}$ Plus2 Pre-stained Protein Standard (\#LC5925) were subjected to electrophoresis in a $3-8 \%$ Tris acetate Nupage gel with Tris acetate running buffer for $60 \mathrm{~min}$ at $150 \mathrm{~V}$ or $4-12 \%$ Bis-Tris Protein Gels with MOPS buffer for $35 \mathrm{~min}$ at $200 \mathrm{~V}$. Subsequent electro blotted by an iBlot device (Invitrogen) on nitrocellulose membrane was performed according to the manufacturer's instructions. Membranes were blocked with BSA $2 \%$ for $1 \mathrm{~h}$ at room temperature and incubated overnight with the primary antibodies. Blots were then washed three times in TBST and incubated in with IRDye secondary antibodies (LI-COR). Visualization and quantification was carried out with the LI-COR Odyssey scanner and software (LI-COR Biosciences). Red color (for actin) was detected at $680 \mathrm{~nm}$ wavelength and a green color (other primary antibodies and tubulin) was detected at $800 \mathrm{~nm}$ wavelength. Quantification was performed using Odyssey software. Intensity values of the bands were normalized for actin or tubulin and expressed as percentage of wild type (100\%). These primary antibodies were used: rabbit anti-Cx43 (Abcam, see above), and antitubulin rabbit antibody (ab, 59680). Secondary antibodies: IRDye $800 \mathrm{CW}$ conjugated goat anti-rabbit IgG $(\mathrm{H}+\mathrm{L})$ highly crossadsorbed (LI-COR; Product No. 926-32211). Dilutions: antitubulin (1:1000); anti-connexin 43 (1:250); secondary antibodies [antibodies (1:10000)].

\section{Quantifications in Enamel Organ}

Paraffin embedded incisor sections were dewaxed in xylene, rehydrated in descending grades of ethanol and stained with $1 \%$ hematoxylin $(15 \mathrm{~min})$ and eosin $(5 \mathrm{~min})$. Sections were dehydrated in ascending grades of ethanol and xylene and mounted in Depex mounting medium. The enamel organs were imaged under 40x objective lenses. Images of secretory and maturation stage of enamel organ were selected based on the anatomical position in the tooth. The number of GJ plaques were counted as previously described (Toth et al., 2010). The investigator was blinded, and GJs (defined as a discernable Cx43-labeled bright fluorescent structure of at least $0.5 \mu \mathrm{m}$ in length, seen in membranes of adjacent cells) were counted per field of view and normalized to the number of the cells in the area number of DAPIstained nuclei) as described before. Stratum intermedium (SI), papillary layer (PL), and ameloblasts were counted separately and combined for a total enamel organ assessment. Statistical analysis was performed by independent $t$-test $(p<0.05)$.

\section{RESULTS}

\section{Connexin 43 Expression Is Important for Enamel Organ Function and Enamel Mineralization}

Histological assessment of enamel organs from $\mathrm{Cx} 43^{\text {flox/flox }}$ control mice revealed a tall, columnar ameloblast cell layer in both the secretory and maturation stage of enamel formation (Figures 1a,c). However, both secretory and maturation stage ameloblasts from $\mathrm{Cx} 43^{\text {flox/flox; DMP1-8kb-Cre mice revealed no }}$ evidence of cell polarity and the columnar profile of this epithelial cell layer was lost (Figures 1b,d; Cx43 $3^{\text {flox/flox;DMP1-8kb-Cre }}$ ) and Figure 1e ( $\mathrm{Cx} 43^{\text {flox/flox }}$ stained with $\mathrm{IgG}$ serum antibody) shows the specificity of the antibody.

To investigate whether absence of CX43 in dental epithelium influences enamel mineralization micro-CT analysis was carried out on jaws of conditional Cx43 ko mice as compared to controls. In upper incisors disruption of the CX43 gene reduced mineral density by $\sim 10 \%$ at late maturation $(p<0.0001)$ but not at secretory and early maturation phase (Figures 2A-D). The fact that in the mutant teeth enamel was hypomineralized at late maturation stage suggested that GJs are required to fully mineralize enamel at late maturation. 

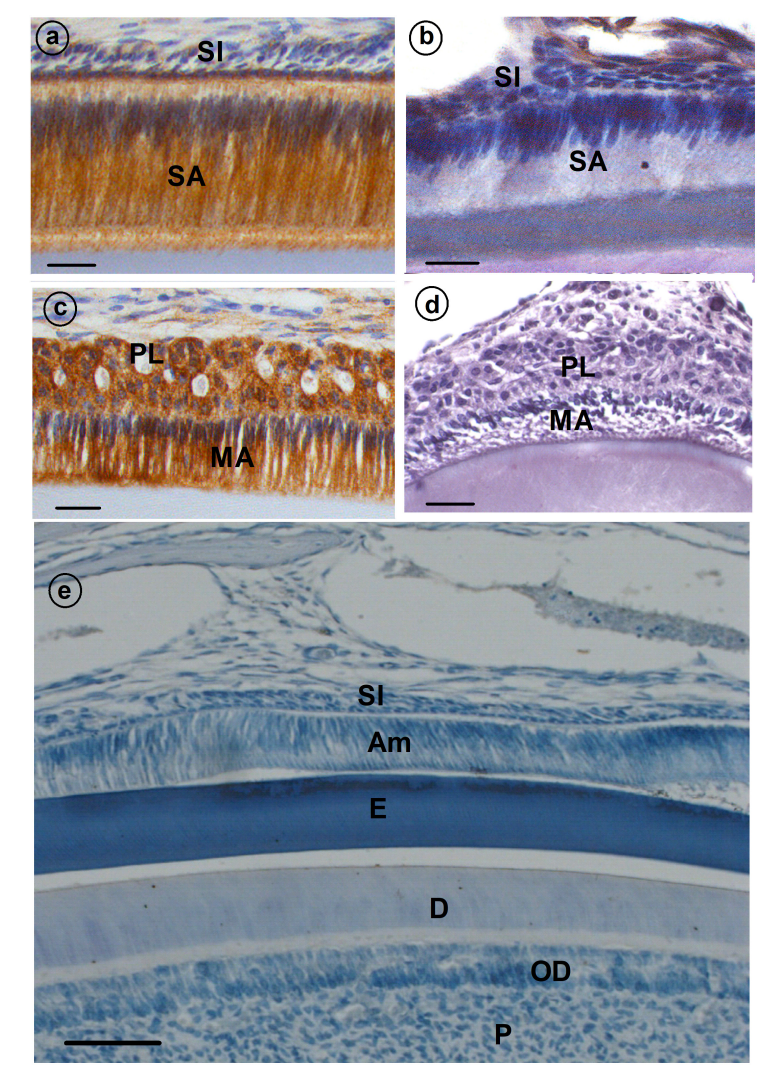

FIGURE 1 | Immunolocalization of gap junction (GJ) protein (CX43) (a-d) in developing mouse teeth. Secretory ameloblasts (SA; a) and maturation ameloblasts (MA; c) are positive for CX43; some staining is also presents in papillary layer (PL; c). (b,d) Cx43 flox/flox;DMP1-8kb-Cre incisor stained with anti-CX43. (e) A sagittal section through the incisor of a control mouse of $\mathrm{Cx} 43 \mathrm{fl} / \mathrm{fl}$ in which normal rabbit lgG was used as primary antibody instead of rabbit anti-Cx43 antibody. All the stainings have been tested in triplicate in three mice. SI, stratum intermedium; SA, secretory ameloblasts; E, enamel; MA, maturation ameloblasts; PL, papillary layer; P, pulp; OD, odontoblasts.

\section{Cx43 Expression Is Increased in Nkcc1-null and Cftr Null Mouse Enamel Organs}

To examine the possible role of GJs in directing the transport of ions from the papillary layer to ameloblasts, tissue sections of mouse mutants with hypomineralized enamel as result from disruption in local $\mathrm{pH}$ regulation (Cftr- null and Nbce1- null mice) were immunostained for $\mathrm{Cx} 43$. In wild type mouse secretory ameloblasts and stratum intermedium strong positive staining for $\mathrm{Cx} 43$ was seen in the basolateral plasma membranes; weaker staining was observed in stellate reticulum cells located between the stratum intermedium and outer enamel epithelium (Figures 3e,k). Wild type maturation ameloblasts and papillary layer stained strongly for Cx43 (Figures 3a-d,h,n).

In Nbce1 null mice (Figures 3f,i) and Cftr null mice (Figures 31,o) the distribution pattern of immunostaining for Cx43 in enamel organs was largely similar as in wild type mice. Protein expression levels of Cx43 in enamel organs by Western

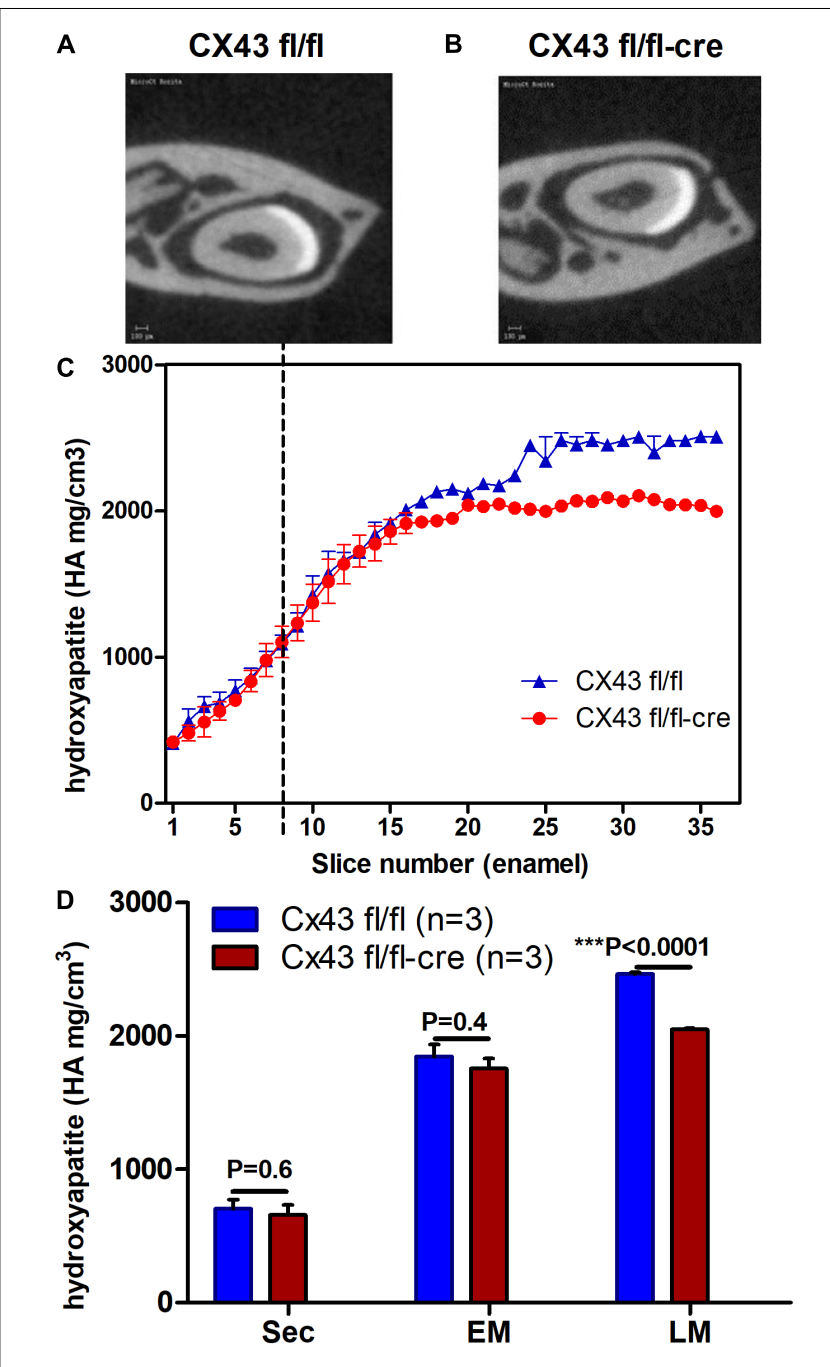

FIGURE 2 | Lower mineral density of enamel in maturation stage ameloblasts of Cx43 $3^{\text {flox/flox; DMP1-8kb-Cre }}$ (A-D) $(n=3)$ suggest the importance of CX43 for enamel mineralization. Mineral density measured by micro-CT plotted against slice numbers (C) (blue color represents $\mathrm{C} \times 43^{f / / f l}$ and red

Cx43 flox/flox;DMP1-8kb-Cre lower incisor). Secretory stage starts from zero and maturation stage starts after dotted lines ( $n=3$ in each group). In (D) the bar graphs with the same color (blue and red) represent measurements of mineral density in different stages of amelogenesis (sec, secretory; EM, early

maturation; LM, late maturation). Figures $(\mathbf{A}, \mathbf{B})$ show virtual cross-section of $\mathrm{C} \times 43^{f / / f l}$ and $\mathrm{C} \times 43^{\text {flox/flox;DMP1-8kb-Cre lower incisor, respectively. The difference }}$ in dentin between $(\mathbf{A}, \mathbf{B})$ is most likely due to differences in angle of the section. The number of teeth per group is $N=3$; error bar represents SE.

blotting showed that Cx43 was increased by $65 \%(p=0.06)$ in Cftr null mice (Figures 3q,r).

Immunohistochemical staining with anti-Cx43 showed that in both Nbce1 null and Cftr null mice the total number of GJs (number of fluorescent $\mathrm{Cx} 43$ positive plaques in the enamel organ), was not different from wild type controls in secretory stage (Figures 3g,j,m,p) but had increased by in maturation stage but significantly increased in the papillary layer in maturation stage (Cftr null mice, $p<0.0001$; for Nbce1 null mice $p=0.005$ respectively; Figures $3 \mathbf{g}, \mathbf{j}, \mathbf{m}, \mathbf{p})$. 

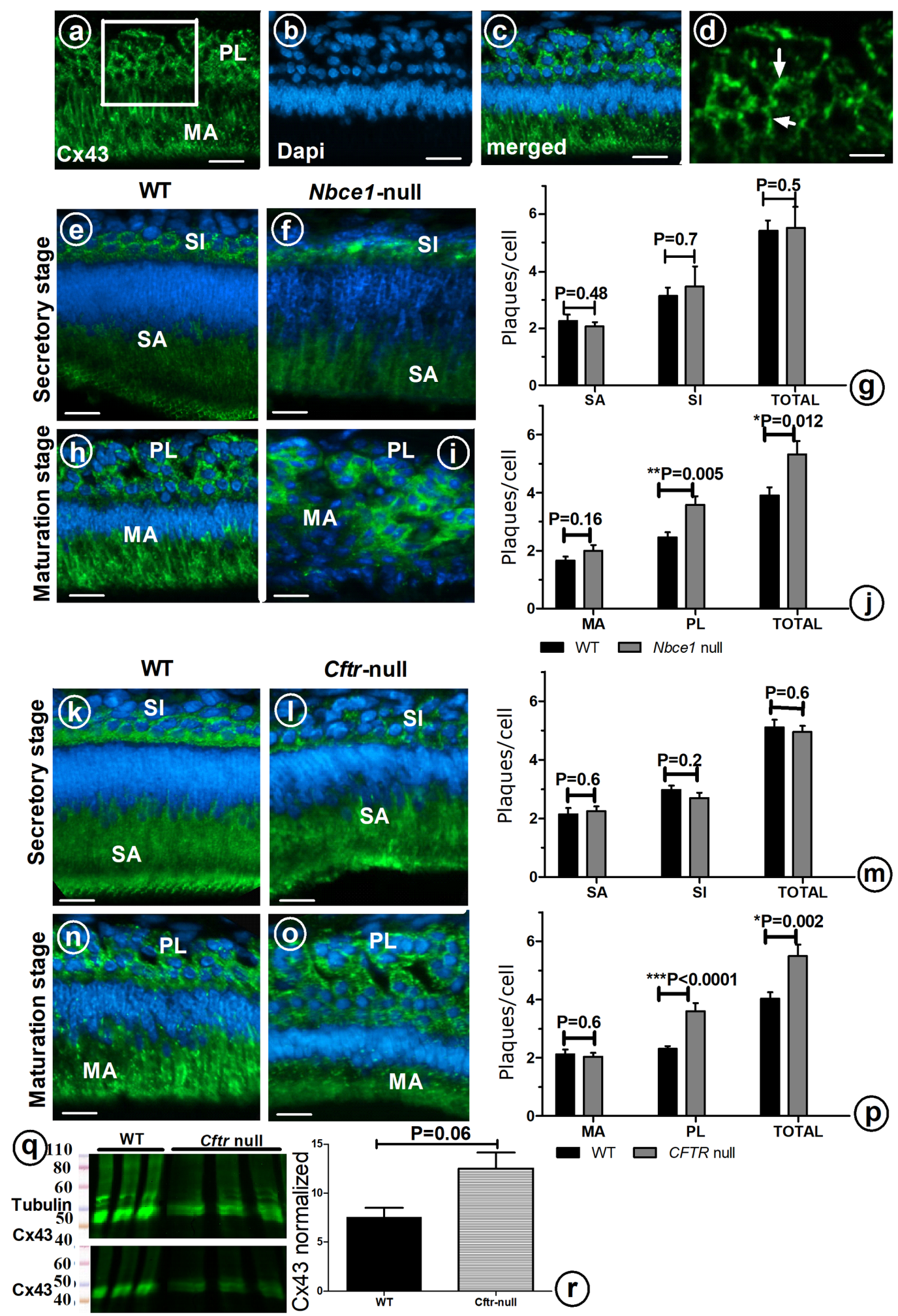

FIGURE 3 | Enamel organ cells of wild type (a-d,e,h,k,n), Nbce1 null (f,i), and Cftr null (l,o). Upper panel shows anti-Cx43 (green) (a), DAPI nuclear staining (blue) (b) and superimposed a on b (c). (d) At high magnification discrete plaques are apparent which were counted per cell type (Indicate a few with arrow). Bar diagram

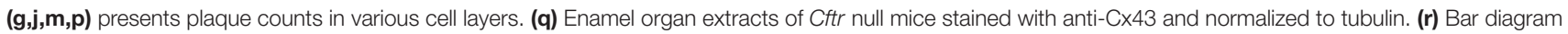
presents the amount of Cx43 protein, although increased in Cftr null mice, the difference did not reach statistical significance ( $n=3$ mice, for each group). SI, stratum intermedium; SA, secretory ameloblasts; MA, maturation ameloblasts; PL, papillary layer. Bar $=50 \mu \mathrm{m}$. 


\section{DISCUSSION}

These results, which show that that differentiating ameloblasts and all cells of the enamel organ, i.e., the stellate reticulum and stratum intermedium express $\mathrm{Cx} 43$, and are consistent with previous reports (João and Arana-Chavez, 2003; Toth et al., 2010). However, our results, which show that the loss of $\mathrm{Cx} 43$ GJs only affect enamel mineralization at the late stage of enamel formation, do not support the proposal by Toth et al. (2010) that Cx43 GJs may mediate protein deposition required for final matrix mineralization.

$\mathrm{Cx} 43^{\text {flox/flox; DMP1-8kb-Cre }}$ mice used in this study, have $\mathrm{Cx} 43$ conditionally deleted in cells expressing dentin matrix protein 1 (DMP1). Though DMP1 is expressed by both ameloblasts and ondotoblasts (D'souza et al., 1997; Martinez et al., 2009), in our study the loss of $\mathrm{Cx} 43$ did not have an obvious effect on odontoblast differentiation and dentin mineralization (data not shown), suggesting that morphologically changes in differentiating ameloblasts are specifically due to the loss of $\mathrm{Cx} 43$ in ameloblasts. Secretory stage ameloblast differentiation occurs in response to signaling that occur as dentin mineralization is first initiated (Bartlett, 2013), and our finding that secretory ameloblasts of the null mice polarize and have similar morphology to wild type mice, further supports the use of this mouse model to investigate the role of Cx43 GJs in ameloblast mediated enamel bio-mineralization.

Micro-CT analysis showed and effect on mineralization only at the maturation stage of enamel formation in $\mathrm{Cx} 43^{\text {flox/flox;DMP1-8kb-Cre }}$ mice, suggesting an important function for GJs in later enamel matrix mineralization. To test the hypothesis that $\mathrm{Cx} 43 \mathrm{GJs}$ direct transcellular transport of ions between papillary layer cells and ameloblasts to allow final matrix mineralization, we measured the amount of $\mathrm{Cx} 43$ in western blots and counted the Cx43 immunopositive plaques in mouse mutants with established hypomineralization of enamel during maturation stage (Cftr null mice and Nbce1 null mice) (Bronckers et al., 2010; Jalali et al., 2014). Western blots showed an increase of $\mathrm{Cx} 43$ protein in enamel organs of Cftr null mutant; immunohistochemically more $\mathrm{Cx} 43$ plaques were counted in papillary layer of Cftr null and $\mathrm{Nbce} 1$ null mice than in wild type controls. These findings suggest that an increase of the number of GJs can occur to increase ion transport through dental epithelium intracellularly when ion exchangers do not function properly.

\section{REFERENCES}

Bartlett, J. D. (2013). Dental enamel development: proteinases and their enamel matrix substrates. ISRN Dent. 2013:684607. doi: 10.1155/2013/684607

Bivi, N., Condon, K. W., Allen, M. R., Farlow, N., Passeri, G., Brun, L. R., et al. (2012). Cell autonomous requirement of connexin 43 for osteocyte survival: consequences for endocortical resorption and periosteal bone formation. J. Bone Miner. Res. 27, 374-389. doi: 10.1002/jbmr.548

Bronckers, A., Kalogeraki, L., Jorna, H. J., Wilke, M., Bervoets, T. J., Lyaruu, D. M., et al. (2010). The cystic fibrosis transmembrane conductance regulator (CFTR) is expressed in maturation stage ameloblasts, odontoblasts and bone cells. Bone 46, 1188-1196. doi: 10.1016/j.bone.2009.12.002

D’souza, R., Cavender, A., Sunavala, G., Alvarez, J., Ohshima, T., Kulkarni, A., et al. (1997). Gene expression patterns of murine dentin matrix protein 1 (Dmp1)
Ion exchangers are required to regulate $\mathrm{pH}$ resulting from the release of hydrogen ions that acidify the enamel matrix as hydroxyapatite mineral is formed (Lacruz et al., 2010a, 2012, 2013). At earlier stages of enamel formation the release of hydrogen ions is buffered by amelogenins in the enamel matrix (Guo et al., 2015). Up-regulation of amelogenin in Gja1Jrt/p (in Gja1Jrt/p mice the expression of $\mathrm{Cx} 43$ is reduced), ameloblasts suggests that compensation of amelogenins in the absence of GJ proteins may responsible for enamel matrix mineralization at secretory stage of amelogenesis. However, in the maturation stage, where we saw hypomineralization in the $\mathrm{Cx} 43^{\text {flox/flox;DMP1-8kb-Cre }}$ mice, the regulation of matrix acidification by ion transporter(s)/channel(s)/exchanger(s) is crucial.

Taken together, the results of this study support the importance of GJs in ion transport through the enamel organ epithelium. Furthermore, these results support the model that the cells of the papillary layer and ameloblasts form a functional unit to transport ions to the ameloblasts for $\mathrm{pH}$ regulation of the final enamel matrix mineralization.

\section{AUTHOR CONTRIBUTIONS}

SA-A and RJ: implemented the experiments and analysis and wrote the manuscript. AB, PD, YZ, JR-D, JdL, and FR: contributed to the design and implementation of the research, manuscript revision, and data analysis. LP: contributed to the design and implementation of the research, manuscript revision, and data analysis, provided the CX43 mice.

\section{FUNDING}

These studies were partially supported by the National Institutes of Health (United States) R01-AR067210 to LP.

\section{ACKNOWLEDGMENTS}

We would like to thank Hannah M. Davis for her help in tissue collection from $\mathrm{Cx} 43^{\text {flox/flox }}$ and $\mathrm{Cx} 43^{\text {flox/flox; DMP1-8kb-Cre }}$ mice.

and dentin sialophosphoprotein (DSPP) suggest distinct developmental functions in vivo. J. Bone Miner. Res. 12, 2040-2049. doi: 10.1359/jbmr.1997. 12.12.2040

Elwood, W. K., and Bernstein, M. H. (1968). The ultrastructure of the enamel organ related to enamel formation. Dev. Dyn. 122, 73-93. doi: 10.1002/aja.10012 20105

Evans, W. H., and Martin, P. E. (2002). Gap junctions: structure and function. Mol. Membr. Biol. 19, 121-136. doi: 10.1080/09687680210139839

Flenniken, A. M., Osborne, L. R., Anderson, N., Ciliberti, N., Fleming, C., Gittens, J. E., et al. (2005). A Gjal missense mutation in a mouse model of oculodentodigital dysplasia. Development 132, 4375-4386. doi: 10.1242/dev. 02011

Gladwin, A., Donnai, D., Metcalfe, K., Schrander-Stumpel, C., Brueton, L., Verloes, A., et al. (1997). Localization of a gene for oculodentodigital syndrome 
to human chromosome 6q22-q24. Hum. Mol. Genet. 6, 123-127. doi: 10.1093/ hmg/6.1.123

Guo, J., Lyaruu, D., Takano, Y., Gibson, C., DenBesten, P., and Bronckers, A. (2015). Amelogenins as potential buffers during secretory-stage amelogenesis. J. Dent. Res. 94, 412-420. doi: 10.1177/0022034514564186

Jalali, R., Guo, J., Zandieh-Doulabi, B., Bervoets, T., Paine, M., Boron, W., et al. (2014). NBCe1 (SLC4A4) a potential pH regulator in enamel organ cells during enamel development in the mouse. Cell Tissue Res. 358, 433-442. doi: 10.1007/ s00441-014-1935-4

Jalali, R., Lodder, J. C., Zandieh-Doulabi, B., Micha, D., Melvin, J. E., Catalan, M. A., et al. (2017). The role of Na: K: 2Cl Cotransporter 1 (NKCC1/SLC12A2) in dental epithelium during enamel formation in mice. Front. Physiol. 8:924. doi: 10.3389/fphys.2017.00924

João, S., and Arana-Chavez, V. E. (2004). Tight junctions in differentiating ameloblasts and odontoblasts differentially express ZO-1, occludin, and claudin-1 in early odontogenesis of rat molars. Anat. Rec. A Discov. Mol. Cell. Evol. Biol. 277, 338-343. doi: 10.1002/ar.a.20021

João, S. M., and Arana-Chavez, V. E. (2003). Expression of connexin 43 and ZO1 in differentiating ameloblasts and odontoblasts from rat molar tooth germs. Histochem. Cell Biol. 119, 21-26.

Lacruz, R., Smith, C., Kurtz, I., Hubbard, M., and Paine, M. (2013). New paradigms on the transport functions of maturation-stage ameloblasts. J. Dent. Res. 92, 122-129. doi: 10.1177/0022034512470954

Lacruz, R. S., Nanci, A., Kurtz, I., Wright, J. T., and Paine, M. L. (2010a). Regulation of pH during amelogenesis. Calcif. Tissue Int. 86, 91-103. doi: 10.1007/s00223009-9326-7

Lacruz, R. S., Nanci, A., White, S. N., Wen, X., Wang, H., Zalzal, S. F., et al. (2010b). The sodium bicarbonate cotransporter (NBCe1) is essential for normal development of mouse dentition. J. Biol. Chem. 285, 24432-24438. doi: 10.1074/ jbc.M110.115188

Lacruz, R. S., Smith, C. E., Moffatt, P., Chang, E. H., Bromage, T. G., Bringas, P., et al. (2012). Requirements for ion and solute transport, and $\mathrm{pH}$ regulation during enamel maturation. J. Cell. Physiol. 227, 1776-1785. doi: 10.1002/jcp. 22911

Laird, D. W. (2006). Life cycle of connexins in health and disease. Biochem. J. 394, 527-543. doi: 10.1042/BJ20051922

Langille, B. L., Zhu, D., Davis, T. C., Juneja, S. C., Kidder, G. M., and Rossant, J. (1995). Cardiac malformation in neonatal mice lacking connexin43. Science 267, 1831-1834. doi: 10.1126/science.7892609
Martinez, E. F., de Silva, L. A., Furuse, C., de Araújo, N. S., and de Araújo, V. C. (2009). Dentin matrix protein 1 (DMP1) expression in developing human teeth. Braz. Dent. J. 20, 365-369. doi: 10.1590/S0103-64402009000500002

Nanci, A. (2012). Ten Cate's Oral Histology Development, Structure, and Function, 8/e. Chennai: Elsevier.

Paznekas, W. A., Boyadjiev, S. A., Shapiro, R. E., Daniels, O., Wollnik, B., Keegan, C. E., et al. (2003). Connexin 43 (GJA1) mutations cause the pleiotropic phenotype of oculodentodigital dysplasia. Am. J. Hum. Genet. 72, 408-418.

Paznekas, W. A., Karczeski, B., Vermeer, S., Lowry, R. B., Delatycki, M., Laurence, F., et al. (2009). GJA1 mutations, variants, and connexin 43 dysfunction as it relates to the oculodentodigital dysplasia phenotype. Hum. Mutat. 30, 724-733. doi: 10.1002/humu.20958

Schmitz, J., Teepe, J., Hu, Y., Smith, C., Fajardo, R., and Chun, Y.-H. (2014). Estimating mineral changes in enamel formation by ashing/BSE and microCT. J. Dent. Res. 93, 256-262. doi: 10.1177/0022034513520548

Smith, C. (1998). Cellular and chemical events during enamel maturation. Crit. Rev. Oral Biol. Med. 9, 128-161. doi: 10.1177/10454411980090020101

Söhl, G., and Willecke, K. (2004). Gap junctions and the connexin protein family. Cardiovasc. Res. 62, 228-232. doi: 10.1016/j.cardiores.2003.11.013

Toth, K., Shao, Q., Lorentz, R., and Laird, D. (2010). Decreased levels of Cx43 gap junctions result in ameloblast dysregulation and enamel hypoplasia in Gja1Jrt/+ mice. J. Cell. Physiol. 223, 601-609. doi: 10.1002/jcp.22046

Weintraub, D. M., Baum, J. L., and Pashayan, H. M. (1975). A family with oculodentodigital dysplasia. Cleft Palate J. 12, 323-329.

Wen, X., Lacruz, R. S., Smith, C. E., and Paine, M. L. (2014). Gene-expression profile and localization of $\mathrm{Na}^{+} / \mathrm{K}^{+}$-ATPase in rat enamel organ cells. Eur. J. Oral Sci. 122, 21-26. doi: 10.1111/eos. 12106

Conflict of Interest Statement: The authors declare that the research was conducted in the absence of any commercial or financial relationships that could be construed as a potential conflict of interest.

Copyright (C) 2018 Al-Ansari, Jalali, Plotkin, Bronckers, DenBesten, Zhang, RaberDurlacher, de Lange and Rozema. This is an open-access article distributed under the terms of the Creative Commons Attribution License (CC BY). The use, distribution or reproduction in other forums is permitted, provided the original author(s) and the copyright owner are credited and that the original publication in this journal is cited, in accordance with accepted academic practice. No use, distribution or reproduction is permitted which does not comply with these terms. 